\title{
Cobalt chloride induces metaphase when topically applied to larvae and pupae of the stingless bee Melipona scutellaris (Hymenoptera, Apidae, Meliponini)
}

C. Ueira-Vieira ${ }^{1}$, R.R. Tavares ${ }^{1}$, S. Morelli ${ }^{2}$, B.B. Pereira ${ }^{1}$, R.P. Silva ${ }^{1}$, A.R. Torres-Mariano ${ }^{2}$, W.E. Kerr ${ }^{1}$ and A.M. Bonetti ${ }^{1}$

${ }^{1}$ Laboratório de Genética, Instituto de Genética e Bioquímica, Universidade Federal de Uberlândia, Campus Umuarama, Uberlândia, MG, Brasil

${ }^{2}$ Laboratório de Citogenética, Instituto de Genética e Bioquímica, Universidade Federal de Uberlândia, Campus Umuarama, Uberlândia, MG, Brasil

Corresponding author: C. Ueira-Vieira

E-mail: ueira@ingeb.ufu.br

Genet. Mol. Res. 12 (2): 2032-2037 (2013)

Received February 16, 2012

Accepted July 23, 2012

Published February 6, 2013

DOI http://dx.doi.org/10.4238/2013.February.6.1

\begin{abstract}
In order to optimize preparations of bee metaphases, we tested cobalt chloride, which has been used as a metaphase inducer in other organisms, such as hamsters and fish. Four microliters of 65 $\mathrm{mM}$ cobalt chloride aqueous solution was topically applied to larval and pupal stages of the stingless bee Melipona scutellaris. The cerebral ganglion was removed after treatment and prepared for cytogenetic analysis. Identically manipulated untreated individuals were used as controls. The number of metaphases was increased 3-fold in treated individuals compared to controls. The micronucleus test showed no mutagenic effects of cobalt chloride on M. scutellaris cells. We concluded that cobalt chloride is a metaphase-inducing agent in $M$.
\end{abstract}


scutellaris, thus being useful for cytogenetic analyses.

Key words: Cytogenetics; Metaphase; Cobalt chloride; Stingless bee

\section{INTRODUCTION}

Cytogenetic studies in stingless bee (Melipona scutellaris) began with Kerr (1948), whose research was also the precursor to the study of the cytogenetics of the entire tribe. $M$. scutellaris, popularly known in Brazil as uruçu do Nordeste, is a stingless bee with geographic distribution in Alagoas, Bahia, Ceará, Paraíba, Pernambuco, Rio Grande do Norte, and Sergipe States (Camargo and Pedro, 2008). The species of this genus generally present $2 \mathrm{n}=18$ and $\mathrm{N}=9$ chromosomes (Rocha et al., 2002).

An adequate number of metaphases in cytologic preparations is usually obtained only from Hymenoptera individuals in the post-defecating larval stage (Pompolo and Takahashi, 1990; Pompolo and Campos, 1995; Brito et al., 2003; Krinski et al., 2010; Marthe et al., 2010), and no efficient method has been described thus far for obtaining a larger number of metaphases in other stages of development.

Thus, in the present study we tested a simple methodology using cobalt chloride modified from that for fish described by Cucchi and Baruffaldi (1990). This method produced a high number of metaphases in larvae and pupae of M. scutellaris stingless bee, and it is a simple, fast, and efficient means of increasing metaphases in cytogenetic preparations.

\section{MATERIAL AND METHODS}

Cytogenetic analyses were carried out using the larval and pupal stages of M. scutellaris stingless bees from Bahia, Brazil (Catu, Murici, and Alagoinhas) maintained at the Uberlândia Meliponary, Uberlândia, MG, Brazil (S 1855', W 48 $\left.17^{\prime}\right)$. The technique described for fish by Cucchi and Baruffaldi (1990) was adapted to bees. We applied $4.0 \mu \mathrm{L} 65 \mathrm{mM}$ cobalt chloride solution topically in the dorsal region of defecating larvae and pupae [white-eyed pupa $(\mathrm{Pw})$, pink-eyed pupa $(\mathrm{Pp})$, brown-eyed pupa $(\mathrm{Pb})$, brown-eyed pupa with light pigmented body $(\mathrm{Pbl})$, black-eyed pupa with pigmented body $(\mathrm{Pbd})]$ of $M$. scutellaris. Larvae and pupae were conserved in an oven at $32^{\circ} \mathrm{C}$ with $85 \%$ relative humidity maintained using a saturated $\mathrm{KCl}$ solution (ASTM Standard, 2002). After cobalt chloride application, the cerebral ganglia were extracted and slides were prepared. Identically manipulated controls received 1 $\mu \mathrm{L}$ distilled water (solvent for cobalt chloride solution).

The chromosomes were obtained from M. scutellaris cerebral ganglia according to a method described by Imai et al. (1988). After dissection on a slide in hypotonic colchicine solution, each cerebral ganglion was transferred to another slide with 2 drops of fixative I $(1.25 \mathrm{~mL}$ glacial acetic acid:1.5 mL ethanol:2 mL distilled water). Excess fluid was removed by tipping the slide, and the procedure was repeated. The tissue was disaggregated and 2 drops of fixative II ( $2 \mathrm{~mL}$ ethanol: $2 \mathrm{~mL}$ distilled water) were added before the evaporation of fixative I. Excess fixative II was removed and 2 drops of fixative III (glacial acetic acid) were added. After drying at room temperature for $24 \mathrm{~h}$, the material was stained with Giemsa in Sorënsen buffer (0.06 $\mathrm{M} \mathrm{NaHPO}_{4}$ and $0.06 \mathrm{M} \mathrm{KH}_{2} \mathrm{PO}_{4}, \mathrm{pH} 6.8$, at a 1:30 proportion) for $20 \mathrm{~min}$. The material was washed in running water, examined under a light microscope (Microphot-FXA, Nikon, Japan), 
photographed on ASA 125 film, and copied on Kodachrome RC paper, S3 contrast, USA. The number of metaphase chromosomes was counted for each treatment; 10 treated and 10 control bees (treated with distilled water) were analyzed. The average numbers of chromosomes in each treatment were compared using the Student $t$-test with 5\% probabilities. All analyses were conducted using the BioEstat 5.0 statistical software (Ayres et al., 2007).

We used a micronucleus assay to test cobalt chloride genotoxic effects in the brain of $M$. scutellaris cerebral ganglia. Ten larvae and 10 pupae were treated with cobalt chloride and distilled water (control) and were dissected and placed on a slide. The neural cells were mechanically separated using needles. The cells were fixed with methanol for $5 \mathrm{~min}$, and then the fixation was removed and the slides were allowed to dry for $24 \mathrm{~h}$. Slides were stained with Giemsa in Sorënsen buffer as above for $20 \mathrm{~min}$. The material was washed in running water, examined under a light microscope (Microphot-FXA, Nikon), and photographed. We examined 300 cells per blade, and 5 repetitions of each treatment were carried out totaling 1500 cells.

The values of micronucleus brain ganglia in the treatment and control groups were used to build a table of contingency. We then used the chi-square test to determine whether the increase in micronuclei after treatment with cobalt chloride solution was near the expected frequency. All analyses were conducted using the BioEstat 5.0 statistical software (Ayres et al., 2007).

\section{RESULTS AND DISCUSSION}

The results showed that the number of metaphases in the Pw cerebral ganglia of $M$. scutellaris treated with $65 \mathrm{mM}$ cobalt chloride was significantly increased $(\mathrm{P}<0.001$, Student $t$-test) compared with that in cytogenetic preparations from control individuals (Figure 1). Applications at intervals of $5 \mathrm{~h}$ to 7 days were tested, and the best time at which to obtain the results presented here was $24 \mathrm{~h}$.

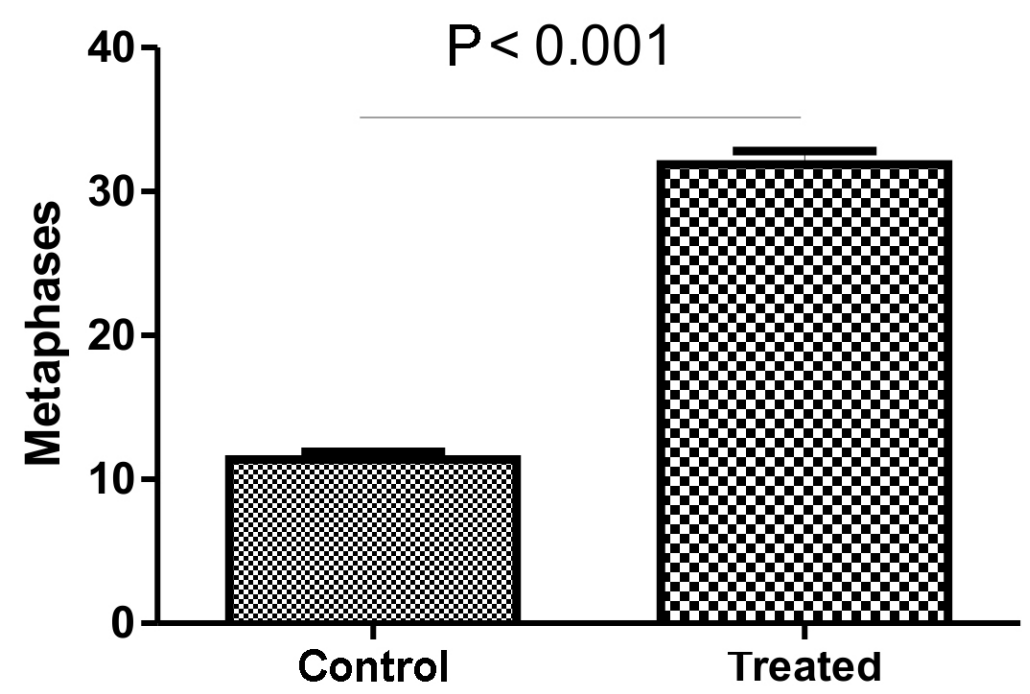

Figure 1. Numbers of metaphases in cerebral ganglia from worker pupae of Melipona scutellaris treated with cobalt chloride $(\mathrm{N}=10)$ and controls $(\mathrm{N}=10)$. Bars indicate a significant difference $(\mathrm{P}<0.001$, Student $t$-test $)$ between the numbers of metaphase from treated and control bees. 
Metaphases were obtained from larvae and pupae ( $\mathrm{Pw}, \mathrm{Pp}, \mathrm{Pb}, \mathrm{Pbl}$, and $\mathrm{Pbd}$ ) without treatment, which displayed a decreased number of metaphases with increasing pupa age. Treated bees displayed 3-fold increases in metaphases compared with the number produced by controls in all stages analyzed. In addition, the results showed no changes in the number and morphology of the chromosomes from larvae and pupae of M. scutellaris after treatment with cobalt chloride (data not shown).

The cerebral ganglia of bees treated with cobalt chloride were analyzed through micronucleus assay to verify the genotoxic effects of the product. The results showed a small increase in the production of micronuclei (Table 1) that was not significant ( chi square $=0.5633$, $\mathrm{P}>0.05$ ). Treatment with cobalt chloride does not produce micronuclei in a meaningful way in the concentration and development phases analyzed, which makes their use feasible for the production of a large number of metaphase in bees.

Table 1. Number and percentage of micronucleus in the brain of worker pupae of Melipona scutellaris treated
with cobalt chloride and control.
\begin{tabular}{lccc} 
Treatment & No. of cells analyzed & No. & Micronucleus \\
\cline { 2 - 4 } & 1500 & 13 & 0.87 \\
\hline Water & 1500 & 26 & 1.73 \\
Cobalt chloride & &
\end{tabular}

$\chi^{2}=0.5633 ; \mathrm{P}>0.05$.

Conventional cytogenetic preparations in bees are generally easy and fast to analyze; however, the fixed material degrades quickly and few metaphases occur per slide, necessitating the dissection of many bees to manufacture slides that yield suitable results using these techniques. Herein we describe a new method of metaphase induction in bees using cobalt chloride solution. With the development of this technique, which consists of a simple topical application of chloride cobalt solution, we increased the number of metaphases up to 3 -fold. Topical treatment with cobalt chloride solution demonstrated that this compound is a potent inducer of metaphase in larvae and pupae of Melipona.

Cucchi and Baruffaldi (1990) recommended an injection of $500 \mu \mathrm{L} 65 \mathrm{mM}$ cobalt chloride solution per $100 \mathrm{~g}$ body weight in fish. We opted for topical application, and the quantity that produced the best results in bees was $4 \mu \mathrm{L} 65 \mathrm{mM}$ cobalt chloride solution per individual.

Many reports detail the use of the cerebral ganglia of Hymenoptera for cytogenetic preparations (Pompolo and Takahashi, 1990; Costa et al., 1993; Rocha et al., 2002; Lopes et al., 2008; Krinski et al., 2010). Studies that investigated cytogenetics in Melipona have not thus far reported preparations of metaphase chromosomes during various pupa ages. Advancing age decreases cell divisions in the cerebral ganglia of pupae and, therefore, the use of the brain tissue of pupae with advanced age in cytological preparations is unsuitable for analysis.

The mechanisms through which cobalt chloride induces metaphases and intensifies their numbers and way in which the cell cycle is influenced or altered are unknown. Cobalt is known to act on RNA transcription. Tres et al. (1972) observed a positive correlation between RNA synthetic activity and the quantity of cations in the nucleus in mouse cells, results that indicated the effect of cobalt chloride on RNA polymerase, the activity of which is dependent on divalent cations. Okail (2010) showed that cobalt chloride is a chemical inducer of hypoxiainducible factor- $1 \alpha$ protein and increases the proliferation of a U251 human glioblastoma cell 
line. The effects of cobalt chloride on the proliferation of mouse AtT-20 cells is concentrationand time-dependent (Pan et al., 2011). These findings and ours suggest that cobalt chloride can induce cell proliferation in mammalian, fish, and insect cells.

Males of Mesocricetus auratus treated with cobalt chloride exhibit a significant increase in hyperdiploid and pseudodiploid somatic cells and meiotic I cells (Farah, 1983). The effect of cobalt chloride in inducing chromosomal aberrations has been observed in mice in vivo (Palit et al., 1991), and its genotoxic activities have been tested in vivo in Drosophila melanogaster by Ogawa et al. (1994) and in mice somatic and germ cells by Hassan et al. (2006). In M. scutellaris, we found no changes in the number and morphology of the chromosomes after treatment with cobalt chloride, and the micronucleus assay showed that the applied concentration of cobalt chloride was not mutagenic in bees.

Our results demonstrated that cobalt chloride is an efficient metaphase inducer in bees, increasing the number of metaphases in treated individuals compared with that in untreated controls. The compound does not change the number or morphology of chromosomes and micronuclei, and it can be used in cytogenetic preparations of bees to increase the number of metaphases and facilitate analysis.

\section{ACKNOWLEDGMENTS}

Research supported by Universidade Federal de Uberlândia, Conselho Nacional de Desenvolvimento Científico e Tecnológico (CNPq), Coordenação de Aperfeiçoamento de Pessoal de Nível Superior (CAPES), and Fundação de Amparo à Pesquisa de Minas Gerais (FAPEMIG).

\section{REFERENCES}

ASTM Standard (2002). Standards Practice for Maintaining Constant Relative Humidity by Means of Aqueous Solutions. American Society for Testing Materials, Philadelphia.

Ayres M, Ayres M Jr, Ayres DL and Santos AS (2007). Aplicações Estatísticas nas Áreas das Ciências Bio-Médicas. 5th edn. BioEstat, Belém.

Brito RM, Caixeiro APA, Pompolo SG and Azevedo GG (2003). Cytogenetic data of Partamona peckolti (Hymenoptera, Apidae, Meliponini) by $\mathrm{C}$ banding and fluorochrome staining with DA/CMA3 and DA/DAPI. Genet. Mol. Biol. 26: 53-57.

Camargo JMF and Pedro SRM (2008). Meliponini Lepeletier, 1836. In: Catalogue of Bees (Hymenoptera, Apoidea) in the Neotropical Region (Moure JS, Urban D and Melo GAR, eds.). Available at [http://www.moure.cria.org.br/ catalogue]. Accessed January 10, 2012.

Costa MA, Melo GAR, Pompolo SG and Campos LAO (1993). Karyotypes and heterochromatin distribution (C-band patterns) in three species of Microstigmus wasps (Hymenoptera, Sphecidae, Pemphredoninae). Braz. J. Genet. 16: 923-926.

Cucchi C and Baruffaldi A (1990). A new method for karyological studies in teleost fishes. J. Fish. Biol. 37: 71-75.

Farah SB (1983). The in vivo effect of cobalt chloride on chromossomes. Braz. J. Genet. 6: 433-442.

Hassan NHA, Fahmy MA, Farghaly AA and Hassan EES (2006). Antimutagenic effect of selenium and vitamins against the genotoxicity induced by cobalt chloride in mice. Cytologia 71: 213-222.

Imai HT, Taylor RW, Crosland MW and Crozier RH (1988). Modes of spontaneous chromosomal mutation and karyotype evolution in ants with reference to the minimum interaction hypothesis. Jpn. J. Genet. 63: 159-185.

Kerr WE (1948). Estudos Sobre o Gênero Melipona. Anais da Escola Superior de Agricultura "Luiz de Queiroz", USP, Piracicaba.

Krinski D, Fernandes A, Rocha MP and Pompolo SG (2010). Karyotypic description of the stingless bee Oxytrigona cf. flaveola (Hymenoptera, Apidae, Meliponina) of a colony from Tangará da Serra, Mato Grosso State, Brazil. Genet. Mol. Biol. 33: 494-498. 
Lopes DM, Pompolo SG, Campos LAO and Tavares MG (2008). Cytogenetic characterization of Melipona rufiventris Lepeletier 1836 and Melipona mondury Smith 1863 (Hymenoptera, Apidae) by C banding and fluorochromes staining. Genet. Mol. Biol. 31: 49-52.

Marthe JB, Pompolo SG, Campos LAO, Salomão TMF, et al. (2010). Cytogenetic characterization of Partamona cupira (Hymenoptera, Apidae) by fluorochromes. Genet. Mol. Biol. 33: 253-255.

Ogawa HI, Shibahara T, Iwata H, Okada T, et al. (1994). Genotoxic activities in vivo of cobaltous chloride and other metal chlorides as assayed in the Drosophila wing spot test. Mutat. Res. 320: 133-140.

Okail MS Al (2010). Cobalt chloride, a chemical inducer of hypoxia-inducible factor- $1 \alpha$ in U251 human glioblastoma cell line. J. Saudi Chem. Soc. 14: 197-201.

Palit S, Sharma A and Talukder G (1991). Chromosomal aberrations induced by cobaltous chloride in mice in vivo. Biol. Trace Elem. Res. 29: 139-145.

Pan S, Pei B, Zhang CR, Fan C, et al. (2011). Effect of hypoxia-inducible factor 1-alpha (HIF-1 $\alpha$ ) on proliferation and apoptosis of adrenocorticotropic hormone (ACTH)-secreting pituitary adenoma cells. Afr. J. Biotechnol. 10: 7510-7517.

Pompolo SG and Takahashi CS (1990). Karyotype of ten species of social wasps (Hymenoptera, Polistinae, Polybiini). Braz. J. Genet. 13: 469-477.

Pompolo SG and Campos LAO (1995). Karyotypes of two species of stingless bees, Leurotrigona muelleri and Leurotrigona pusilla (Hymenoptera, Meliponinae). Braz. J. Genet. 18: 181-184.

Rocha MP, Pompolo SG, Dergam JA, Fernandes A, et al. (2002). DNA characterization and karyotypic evolution in the bee genus Melipona (Hymenoptera, Meliponini). Hereditas 136: 19-37.

Tres LL, Kierszenbaum AL and Tandler CJ (1972). Inorganic cations in the cell nucleus. Selective accumulation during meiotic prophase in mouse testis. J. Cell Biol. 53: 483-493. 